\title{
240 カオス予測器を用いた蒸発量予測制御装置の開発 Development of the steam flow rate control system using chaos predictor
}

\author{
○正 中村 成章（三菱重工業） \\ 正 田熊 昌夫（三菱重工業） \\ 重田 博明（三菱重工業）
}

\author{
高津戸 康弘（三菱重工業） \\ 荒岡 衛（三菱重工業）
}

\begin{abstract}
Shigeaki Nakamura,Mitsubishi Heavy Industries,LTD., 1-8-1 Kanazawa-ku,Yokohama,236-8515 Japan Yasuhiro Takatsudo, Mitsubishi Heavy Industries,LTD.

Masao Takuma, Mitsubishi Heavy Industries,LTD.

Mamoru Araoka, Mitsubishi Heavy Industries,LTD.

Hiroaki Shigeta, Mitsubishi Heavy Industries,LTD.

We developed a predictive steam flow rate control system using generalized radial basis function, focusing on chaotic motion of steam flow rate of refuse incinerator.

Predicted signal has optimized with online learning and predicted time has optimized with real time prediction of reliability of predicted value using Lyapunov exponent.

This system is characterized by tuningless and good performance of reliability of predicted value. This system has been installed and tested at an incineration plant with industrial scale and showed good control performance compared with a conventional control system.
\end{abstract}

Key Words :Predictive Control, Chaos, Radial Basis Function, Steam Flow Rate Control, Refuse Incineration Plant

\section{1.はじめに}

ストーカ式都市ごみ焼却プラントは無破砕のごみをを炉内に 供給するため、ごみエネルギ一、ごみ質の変動が比較的大き く、爰密な定量供給が困難である。そこで、ごみ供給制御は ボイラ出口蒸発量（以下蒸発量）を検出端上し、蒸発量が設 定值に近づくようフィーダ（ごみ供給装置）速度によりごみ 供給量を操作寸る。しかし、蒸発量は炉内燃焼場からの時間 遅れがあり、加えてごみエネルギ一・質の変動があり結果と して蒸発量が大きく不規則に変動方る要因となっている。

この問題を解決寸るため、蒸発量を予測寸ることで燃焼場 からの時間遅れを補償し、ごみ供給を操作寸ることで蒸発量 変動を小さくする試みを始め上する予測制御技術の導入が近 年盛しに行われている(1)、(2)。

ごみ焼却炉の蒸発量予測制御に関する重要な点を挙げると、 (1)ごみエネルギー・質の変動から蒸発量が不規則に変動する がこれを正確に予測すること、(2)予测制御によりフィードバ ック制御した系を予測すること、(3プラントの安全な運転の 為、予測制御安定性を常に保つこと、がある。

本研究では、これらを満たすため、蒸発量予測には蒸発量 の力オス性（短期的な規則性と長期的な不規則性）に着目し た一般化動径基底関数を適用し、予測精度を向上させた。ま た、予測モデルを学習により定期的に更新吉るオンライン学 習を付加し、フィードバック制御系の予測制御を可能とした。 さらに予測精度予測ロジックを付加し、カオス性の強い蒸発 量の予測の困難さを予測、検知を可能とし、オンラインで子 測制御信号の最適化を図った。

1999 年 12 月に実機都市ごみ焼却プラントにて長時間運転 試験を行い装置の予測制御性、装置安定性について検証した。 本報告ではその結果について報告する。

\section{2.蒸発量のカオスと予測}

カオスとは、一見不規則に見える挙動に規則性が内在し、 似通った状態にあっても時間経過後その状態が指数関数的に
異なるような系の状態を指寸。系の予測（闰定）の観点から 見た場合、カオス状態にある系は短期的には規則性があり予 测が可能であり、また長期的には規則性を見出すことは困難 であり、予測不可能であると言える。

実機にお污る蒸発量変動を Fig. 1 に示寸。罒に示されるよ うに、蒸発量変動はごみエネルギ一・質の変動や、燃焼場の 非線形性により不規則に変動する。蒸発量データにカオスが 存在寸ることは渡澳 ${ }^{(3)}$ 、小野等 ${ }^{(4)}$ 、中村等 ${ }^{(5)}$ により示されて いる。

今回実機試験を行った工場の蒸発量データのカオス性につ いて、最大リアプノフ指数（式(1))、自己相関関数（式(2)） の羊え (相関) 時間、相関積分（式(3)）による相関次元を 解析した。Table 1 に結果を示す。

リアプノフ指数は系の初期值敏感性を表し、最大值が 0 よ り大きい值をとりその値が大きい程力オス性が大きい。最大 リアプノフ指数以 0.24 となりカオス性を有するといえる。

自己相関関数の遅れ時間（式(2)の值が最初に0となる值。

その後自己相関関数は急激に0に近づく。）はその值が小さ い程相関時間は小さく、カオス性は大きい。遅れ時間は 145[sec]となり、その後自己相関関数恃急激に0に近づき、 この事からもカオス性を有することがいえる。

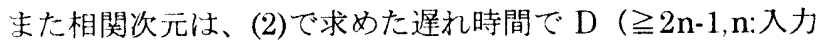
データの次元）次元にデータを埋め込み（その軌道をアトラ クタと呼ぶ)、D の増加とともに $\log (\mathrm{r})-\log (\mathrm{C}(\mathrm{r}))$ が一定の傾 きとなる場合、アトラクタはフラクタル性（相似性）を持ち、 これを相関次元と呼ぶ。相関次元が小さい程系の相似性が高 く、周期的である。相関次元は 3.1 となり、蒸発量のアトラ クタはほぼ 3 次元で構成されるといえる。

これらいずれの解析結果からも本工場の蒸発量データがカ オス性を有寸るといえる。

〔No.00-7〕日本機械学会第 10 回環境工学総合シンポジウム 2000 講演論文集〔’00.7.6,7・川崎市〕 


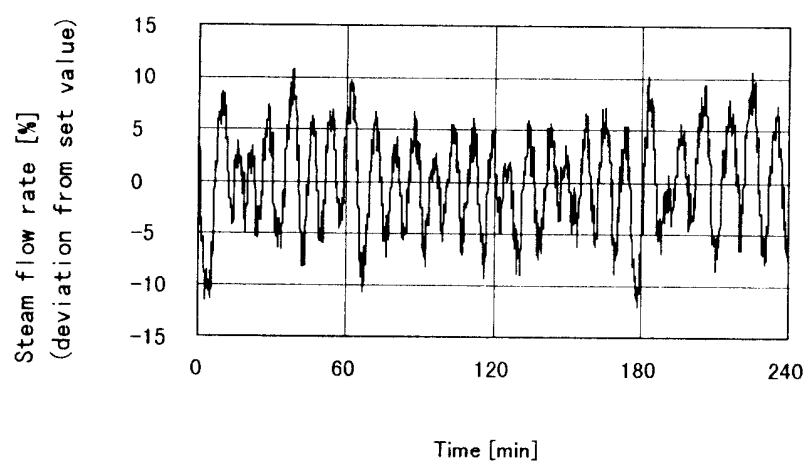

Fig. 1 Steam flow rate fluctuation of refuse incineration plant

$\lambda_{i}=\lim _{N \rightarrow \infty}(1 / N \tau) \sum_{i=0}^{N-1} \log \mid \mathbf{e}_{i}^{\prime}(t)$

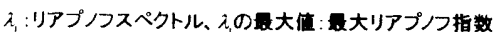

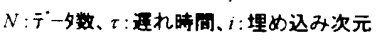

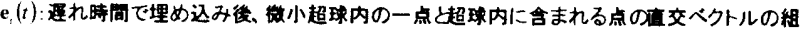

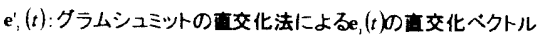

$R(L)=\sum_{t=1}^{N-z} x(t) \cdot x(t-L)$

$R(L)$ : 自己相関関数、 $L:$ 遅九時間、 $N:$ テータ数、 $x(t):$ 入力データ

$C(r)=\frac{1}{N^{2}} \sum_{i, j(1+1)} H\left(r-\left|\mathbf{v}_{i}-\mathbf{v}_{j}\right|\right)$

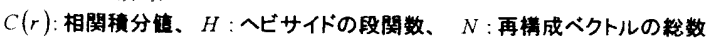

$\mathbf{v}_{i}(t): D$ 次元埋め込み空間における再棈成べクトル

Table1 Chaos analysis of steam flow rate

\begin{tabular}{|l|c|c|}
\hline & unit & value \\
\hline$L_{\text {yyapunov exponent }}\left(^{*}\right)$ & {$[-]$} & 0.24 \\
\hline $\begin{array}{c}\text { Correlation time } \\
\text { (delay time) }\end{array}$ & {$[\mathrm{sec}]$} & 145 \\
\hline Correlation dimension & {$[-]$} & 3.1 \\
\hline
\end{tabular}

$\left.{ }^{*}\right)$ 遅え時間沬自己相関より計算した遅れ時間とした。

カオス性を持つ蒸発量データは短期的には規則性をもつ。 その規則性を同定し、蒸発量の予測を試みた。

蒸発量デー夕の予測には、カオス性を持つ蒸発量データを高 精度に予測可能な、一般化動径基底関数（動径基底関数上線 形自己回㷌モデルのハイブリッドモデル、式(4)）を用いた。 モデルのパラメータは過去の一定時間のデータより最適化さ れる。本モデルは蒸発量データのみを用いて予測を行らため、 予測モデルの事前チューニングが不要という特長がある。

$F(X)=\sum_{h=1}^{N b} C_{h} \exp \left\{\beta_{h} \sum_{i=0}^{D-1}\left[x\left(t-\tau_{i}\right)-\theta_{h}\right]^{2}\right\}+\sum_{i=0}^{D-1} a_{i} x\left(t-\tau_{i}\right)+d$

$X=(x(0), x(1), \cdots, x(t)):$ 入力データ、 $F(X):$ 予測データ

$\tau_{i}:$ 遅九時間、 $D:$ 埋込み次元、 $N b:$ 基底関数の数

$C_{k}, \beta_{k}, \vartheta_{i}, a_{i}, d:$ 学習により最適化されるパラメータ

\section{3.予測制御安定性の向上と蒸発予测制御装置の開発}

長期的な予測制御安定性を向上させるため、以下の機能を 追加し、その効果を確認した。これらの機能を取り人れ、蒸 発量予測制御装置を開発した。

\section{1.オンライン学習機能}

本装㯰ではフィードバック制御系である本制御において、 予測対象の系の变動に迅速に追従し予測精度を向上させるた め、オンラインで蒸発量データを取り込み定期的に予測モデ ルを更新させるオンライン学習機能を付加した。オンライン 学習の効果を Fig. 2 に示寸。学習ロジックの一部改良等に上 り学習間隔 1 分を可能とした。試作機(5) の学習間隔 5 分 (Fig.2 左）と比較して学習毎のモデルのパラメータ変更幅が小さく 系の変動に的確に追従し（Fig.2 右）、さらに正確な予測が可 能となった。
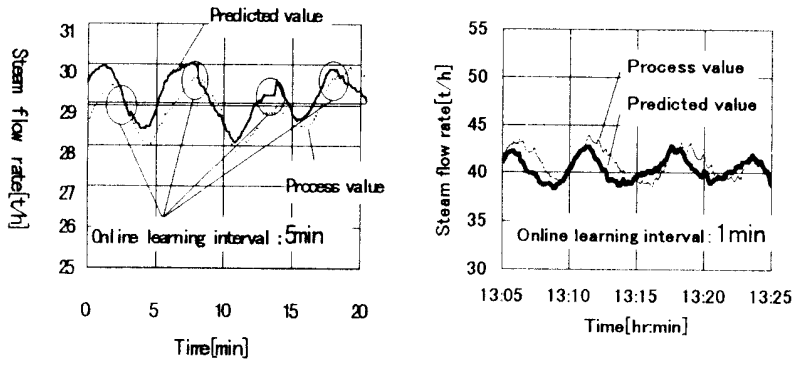

Fig.2 Optimization of predicted signal with online learning

\section{2. 予測精度予測}

カオス性を持つ系（データ）は予測し易い状態にある場合 と、予測し難い状態にある場合がある。カオス性を持つデー タのアトラクタはいくつかの軌道を持ち、それらの軌道が重 なりあった部分では、いずれの軌道にあるのか判別し難いの で尒測は困難であり、重ならない部分では予測が容易である。 Fig. 3 に力オス性を持つデータのアトシク夕多示，2 種類 の軌道をもち、状態が A であるとき Aに移行寸るこ上は子， 測し易い状態であるが、状態が B である時 B 1 か B'2 に移 行寸るかは予测し難い。

本装置ではデータの予測困難さをリアプノフ解析により検 出した。リアプノフ指数の計算には、デー夕数が少ない場合 に適子るSano、Sawada の方法淿在用いた (式(1)) リア ノフ指数をオンラインで計算し、その值が大きい程、初期值 敏感性が高く予測困難であることから予測先時間を小さくし、 值が小さい程、予測が容易であることから子测先時間を大き くする。

予測精度予測の効果を Fig.4に示寺。リアナナノフ指数 (Lyapunov exponent) の増大（11:34）の後、予測值 (predicted value) はプロセス值 (process value) と異な る結果となり予測精度が悪化している。このことはリアア゚， フ指数により予測困難となることを事前に予测可能であるこ とを示吉。その際、予測先時間を小さくした予测制御信号 (control value) により制御することで予測制御性が向上小 る結果が得られた。 
Lyapunov exponent : small

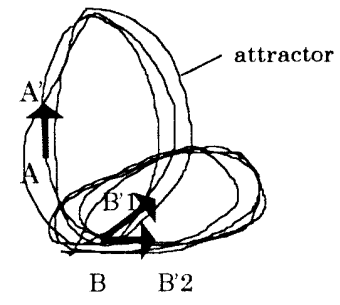

Lyapunov exponent : big

Fig.3 Attractor of Chaotic montion and predictability of system

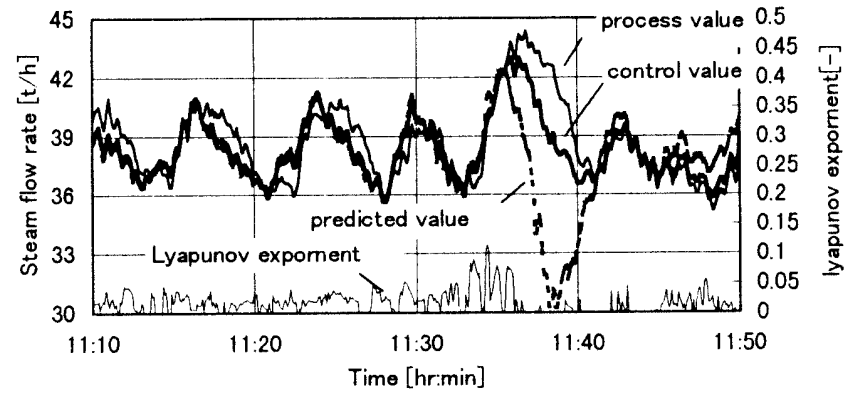

Fig.4 Reliability of predicted data

\section{3.蒸発量予測制御装置の開発}

蒸発量予測制御装置の構成を Fig. 5 に示与。予測制御装置 はパソコンと入出力ボードで構成される。蒸発量データをフ ラント制御装置からオンラインで取り込み、過去一定時間の データから予測モデルのパラメータを最適化する。予測モデ ルはオンライン学習により予測対象系の変化に追従し正確な 予測が可能となる。

また、予測精度予測ロジックにより予測の困難さを予測し、 予測先時間を変更し、常に最適な予測制御信号を算出寸る。

蒸発量の設定值と予測制御信号を基にフィーダ速度を操作 交る。

予測制御信号によりフィーダ速度を操作することで、炉内 燃焼からのごみ供給の時間遅れが補償され、蒝発量変動が小 さくなる。

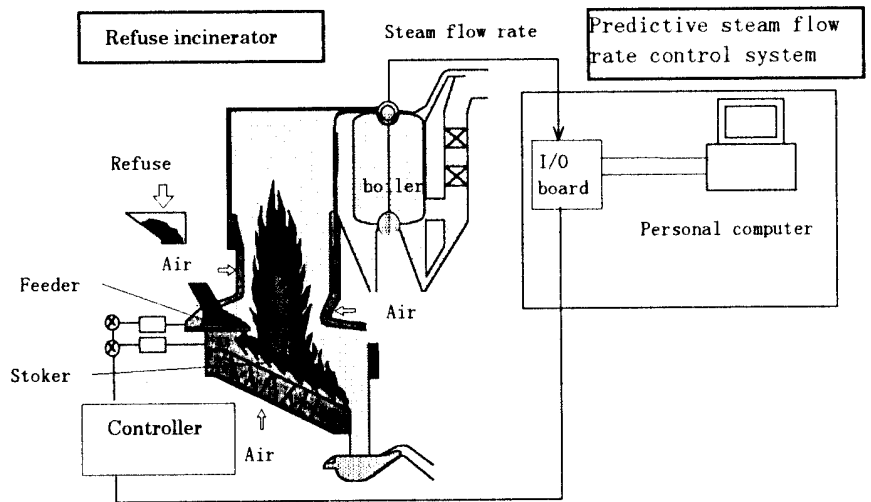

Fig.5 Steam flow rate control system using chaos predictor

\section{4.長期英機試験}

長時間にわたり実機（ストーカ式）にて予測制御試験を行 った。制御試験は 17 日間行った。

予測結果を Fig.6 に示す。予測データと最大予測先時間で ある $90[\mathrm{sec}]$ 先の実データを重ね合せた。周期、振幅とも良 く一致した。予測精度として予測值と実測值の二乗平均誤差
を標準偏差により規格化した RRMSE(Relative Root Mean Square Error、式(5))の計算結果を Fig.7 に示す。学習間隔 1分]とした場合、予測精度が向上した。また、予測制御時 にも RRMSE $=0.60$ と予測精度が高く、予測のみ（予測制御 無）の場合（RRMSE=0.52）とほぼ同等の結果が得られた。

予測制御時の代表的な蒸発量変動データを Fig.8 に示す。 既存制御（Fig. 1）と比較すると、既存制御では設定值に対 する変動幅（累積頻度分布 $90 \%$ の值）は 9.0[\%]に対し、予 測制御では $5.8[\%] と 、 35[\%]$ の低減効果を長期的に確認する ことができた。

また、予測制御の効果として、蒸発量が大きく変動した場 合の減衰が速くなる結果が得られた。Fig.9 に例を示す。初 期の大きな変動は運転中まれにおこるアーチング（ごみホッ パでのごみ閉塞）によるごみの供給不足による蒸発量落ち込 みまたは、ごみの過剩投入による蒸発量大等が挙げられるが、 予測制御ではこの際、予測による先行制御により减衰が速く なっていることが分かる。

RRMSE $=\sqrt{\frac{1}{T} \sum_{t=1}^{T}(y(t)-x(t))^{2}} / \sigma$

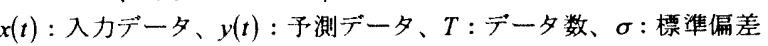

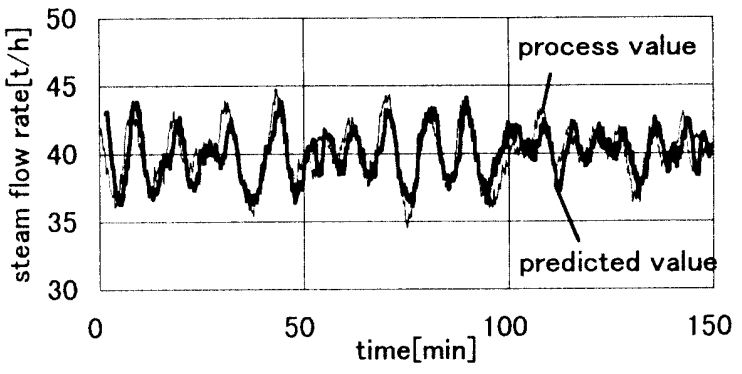

Fig.6 Prediction of steam flow rate with predictive control

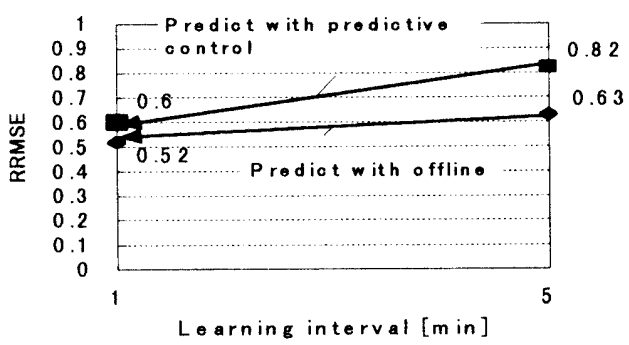

Fig. 7 Reliability of predicted value

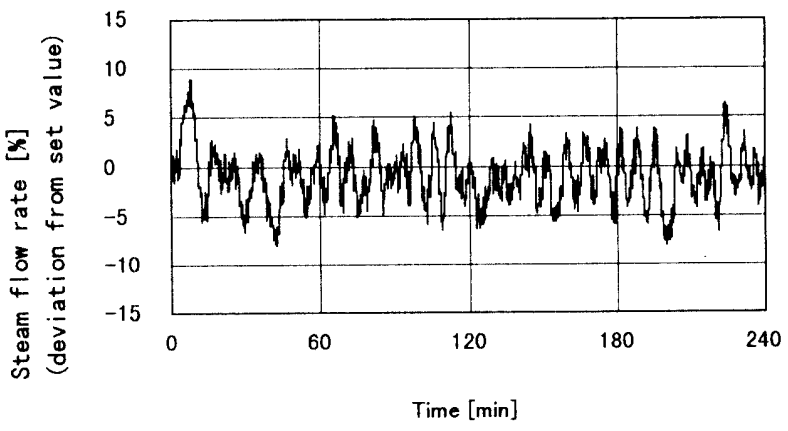

Fig. 8 Steam flow rate with predictive control 

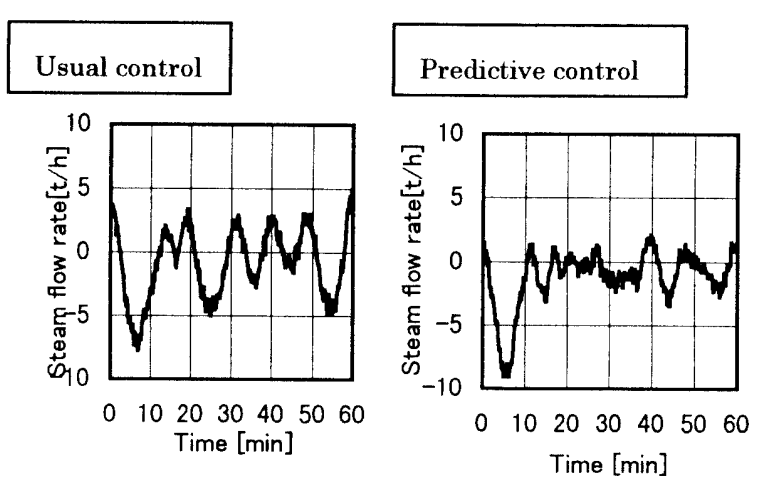

Fig.9 Improvement of damping ratio

\section{5.まとめ}

カオス性（短期的な規則性と長期的な不規則性）をもつご み焼却炬蒸発量の予測に有効な、一般化動径基底関数を予測 モデルとする蒸発量予測制御装置を開発した。

オンライン学習機能により、フィーードバック制御での予測 制御を可能とした。

リアプノフ解析を用いた予測精度予測機能により、予測精 度の予測が可能であることを確認した。本機能を用い、予測 制御信号を最適化し、長期的な予測制御安定性を向上させた。 本装置は、高精度な予測、チューニングレスである事を特 長とする。

実機長期試験により、本装置は 90[sec]先の予測制御が可能 であり、予測制御により従来制御と比較して蒸発量変動が

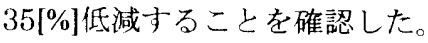

\section{[参考文献]}

(1) 宮本，黑崎,藤山,南部,”流動床ごみ焼却炉の動特性解析と燃 焼制御”, 計測自動制御学会論文集, 32 巻 2 号,pp215223,1996

(2)末松, 中井,小林, 岡田,”流動床焼却炉のモデル予測制御・フ アジィ制御の開発”,エバラ時報,No.184,1999

(3)渡息,”ごみ焼却炬制御系に現れるカオス的現象の解析”、シ ステム/情報合同シンポジウム,pp89-93,1998

(4)小野,三橋,岡田,"ごみ焼却制御におけるカオス”, 日本機械学 会第 72 回通常総会講演論文集,volIII,pp811,1995

(5) 中村,高津戸,山田, ごみ焼却炉カオス蒸発量予測制御装置 の開発”,廃莗物学会講演論文集,pp653-656, 1999

(6)M.Sano,Y,Sawada," Measurement of the Lyapunov Spectrum from a Caotic Time Series",Physical Review Letters, $55,10,1082-1085,1985$ 